\title{
Of Ships and Sealing Wax
}

\section{Alec Douglas}

En 1971, les historiens maritimes les plus éminents des États-Unis et du Canada ont fondé la North American Society for Oceanic History. À l'issue de débats prolongés et de l'introduction de séances d'histoire maritime lors des réunions annuelles des sociétés savantes canadiennes au cours des onze années suivantes, la constitution en société formelle de la Société canadienne pour la recherche nautique a eu lieu en 1984. Cette décision a mené à la production d'un bulletin d'information et, en 1991, à la présente revue, Le Marin du Nord. Le professeur Lewis Fischer de l'université Memorial à Terre-Neuve, le premier rédacteur en chef, a établi des normes d'érudition rigoureuses. Ses successeurs le Dr William Glover et le professeur Roger Sarty ont su maintenir ces normes. Les premiers numéros étaient principalement axés sur le Canada mais, au cours des années, leur contenu s'est élargi; en 2006, cette publication est devenue la revue principale tant pour la SCRN que la $\mathrm{NASOH}$.

$$
\begin{aligned}
& \text { "The time has come," the Walrus said, } \\
& \text { "To talk of many things: } \\
& \text { Of shoes--and ships--and sealing-wax- ..." }
\end{aligned}
$$

In May, 1971, at the invitation of Professor Clark Reynolds, some Canadians went to Orono, Maine, for a meeting organized by the Canadian/US studies department at the University of Maine. Professors Keith Matthews ${ }^{1}$ and Gerry Panting, fresh from acquiring a large portion of the maritime history archive from Liverpool, England, came from Memorial University, Newfoundland. Professor Donald Schurman and some graduate students came from Queens University and the Royal Military College in Kingston. ${ }^{2}$

\footnotetext{
${ }^{1}$ Keith Matthews (1938 - 1984) was a pioneer in the study of West of England and Newfoundland fisheries. He amassed and created a huge collection of documents and papers relating the early fisheries and settlement of Newfoundland and the individuals who were involved in its economic and political life.

${ }^{2}$ Donald Schurman, (1924 - 2013), who earned his doctorate at Sidney Sussex College, Cambridge University in England, has been recognized for creating a new approach to the development of strategic thinking in the Royal Navy in the nineteenth century, and he has had a profound effect on the study of naval history in Canada. He was the first non-British fellow at
}

The Northern Mariner/Le marin du nord, XXVI, No. 3 (July 2016), 247-258. 
Public transportation from Ottawa to Orono was difficult (incredible train timetables and complicated flight schedules), so Professor Schurman invited me to join the Kingston delegation driving in his new car. He said it was fine, because he had just bought what he called this new big American vehicle. It was in fact a compact, there were six of us in it, we were all over six feet tall. After crossing the border by a back road in which our wheels were up to the hubcaps in mud (it was early spring), and lunch in a small town south of the border, the car refused to start. Fortunately, it was standard drive and we were able to start it with a vigorous push, then kept it running until we reached our destination. We survived the crush by rotating seat positions every couple of hours. A garage in Orono fixed the car over the weekend.

The meeting, thanks especially to the hospitality and excellent organisation of Clark Reynolds ${ }^{3}$ and Bill McAndrew, ${ }^{4}$ was a social success, and a remarkable academic occasion. The presence of Gerald Graham, Samuel Eliot Morison and Robert Greenhalgh Albion gave special prestige to the event. The principal reason for the meeting, at which several papers were presented, was to form a society devoted to the study of maritime (that is, marine as opposed to maritime provinces) history. Clark Reynolds, a devout Mahanist, coined the term "Oceanic," which was acceptable to us all, and said that such a society would form the basis of an American Commission of the International Commission of Maritime History. ${ }^{5}$ Since Keith Matthews was already the Canadian delegate to the International Commission, we explained that although we were glad to help, we would need to form a separate Canadian society to meet our own needs. It would be awkward, indeed

Sidney Sussex College. His doctoral thesis would eventually be published in 2000 as Imperial Defence, 1868-1887 (by Donald Mackenzie Schurman; edited by John Beeler). After the family's return to Canada and a year at the University of Alberta in Edmonton, Don had embarked on a long and distinguished career at the Royal Military College in Kingston, Ontario. He wrote and published his first book, The Education of a Navy, (London: Cassell, 1965), before moving "across town" to become part of the History Department of Queen's University, and where in addition to his work on naval history he became involved with the Disraeli Project. His doctoral thesis, which had focused on the development of strategic thinking in the Royal Navy, would influence a new generation of naval historians in both the United States and the United Kingdom.

${ }_{3}$ Clark Reynolds (1939 - 2005) began his career as an instructor, and later an associate professor, in the Department of English, History, and Government at the US Naval Academy in 1964-1968. From there, he went to the University of Maine, where he served in the Department of History from 1968 to 1976 as associate, and then full professor. While at the University of Maine, he and William J. McAndrew conducted seminars in maritime and regional history. Reynolds became a pivotal figure in helping to organize the North American Society for Oceanic History serving as that organization's first secretary-treasurer. (“Clark G. Reynolds," Wikipedia, accessed 11 June 2016).

${ }^{4}$ Bill McAndrew, then an assistant professor at the University of Maine, would some years later decide, when his children came home reciting the American oath of independence, it was time to come home to Canada. That brought him to the Directorate of History at Canadian National Defence Headquarters, where he made significant contributions to the official history of the Royal Canadian Air Force. He and Terry Copp wrote, Battle Exhaustion: Soldiers and Psychiatrists in the Canadian Army, 1939-1945, (Montreal and Kingston: McGill Queen's University Press, 1990).

${ }^{5}$ North American Society for Oceanic History, Newsletter, Winter 1975, Vol. 1 No. 1. 
unacceptable, to have been represented by US delegates to the International Commission.

Consequently, from the very first meeting of what would become the North American Society for Oceanic History (NASOH), Canadian members were understood to have their own organization within the International Commission. On 15 April, 1980, Ken Mackenzie (then archivist of the Canadian Postal Museum), Professor David Ruddy, (of the Collège Militaire Royal at St Jean, Quebec, and former vice president, Centre d'histoire et d’archaéologie sub-aquatique), Walter Zacharchuk (Parks Canada, head of underwater research), Marc Théoret (an underwater archaeologist then diving on HMS Lowestoffe sunk off Pointe-auxTrembles on 19 May 1760), and Alec Douglas, (director of history, National Defence Headquarters), signed a letter to eighty Canadian historians and underwater archaeologists with a questionnaire on the possible creation of a Canadian society for the study of maritime history. There were nineteen responses, fourteen of which favoured the proposal, ${ }^{6}$ and a year later we announced the formation of a Canadian sub-commission of the International Commission for Maritime history with Professor Keith Matthews (Memorial University), as president, Professor Dick Unger (University of British Columbia) as vice-president ${ }^{7}$ and Professor Gerry Panting (Memorial University) as secretary/treasurer. ${ }^{8}$

At the same time we formed the Canadian Society for the Promotion of Nautical Research, or as we later called it, the Canadian Nautical Research Society. Faye Kert $^{9}$ will remember that with Dan Harris, a former naval person - during the Second World War Dan had served as assistant British naval attaché in Stockholm ${ }^{10}$ - we drew up our constitution and fulfilled the requirements of Revenue Canada to acquire charitable status. The incorporation of the society marked the culmination of work begun at a meeting held at the University of Ottawa on 10 June 1982. Keith Matthews was in the chair. In May, 1984, we had our first publication, The Precambrian, the Newsletter of "the Central Canada Section of the Canadian Society for the Promotion of Nautical Research," edited by Ken Mackenzie, which arose from a meeting on 10 February 1984 to discuss Canadian marine archives. As he explained, the main purpose of the newsletter was "to pave the way for a permanent journal for the CSPNR ... unabashedly patterned on The Mariner's

\footnotetext{
${ }^{6}$ Canadian War Museum, W.A.B. Douglas textual records 58C 3 30. 1-20.

${ }^{7}$ Professor Unger, of the Department of History at the University of British Columbia, served as vice president from 1981-1987.

${ }^{8}$ Douglas, op.cit.

9 Then the public relations officer for the Canadian War Museum, Faye Kert would become book review editor for The Northern Mariner in 2003. She earned her PhD from the University of Leiden and is the author of Privateering and Naval Prize in Atlantic Canada in the War of 1812 (American Maritain Association Publication, 1997), Trimming Yankee Sails: Pirates and Privateers of New Brunswick (Goose Lane Editions \& NBMHP, 2005), Prize and Prejudice (Fredericton NB, 2005), and Privateering Patriots and Profits in the War of 1812 (John Hopkins University Press, 2015).

${ }^{10}$ Daniel Harris and Philip Chaplin, Observed Secretly: Northern Window, (Ottawa: Helmsman Publications, 2006).
} 
Mirror. We are timing its initial appearance for 1986, to coincide with the transportation-oriented international fair to be held in Vancouver."

Sadly Keith Matthews, our first president, died on 10 May 1984, just before the society's first conference. That remarkable scholar, Canada's representative in the International Commission of Maritime History, was a man of parts. His delight in jazz piano was infectious. He had been the inspiration behind the maritime studies department of Memorial University, and it was the continuing efforts by members of that department, Professors Lewis "Skip" Fischer, ${ }^{11}$ Gerald Panting ${ }^{12}$ (who was elected president of the society) and Olaf Janzen ${ }^{13}$ that ensured the continuing participation of Memorial in establishing the CNRS and the society's journal. When in the following month we held our first conference ${ }^{14}$ at the Royal Military College of Canada in Kingston, Ontario, Emily Cain, Alec Douglas, Lewis Fischer, Dan Harris, Faye Kert, Ken Mackenzie, Marc Milner. R.L. Schnarr, Maurice Smith, Dugald Stewart and Glenn Wright attended the business meeting where Skip Fischer raised the subject of a journal. To quote from the minutes:

Maurice Smith observed it was a function of membership. He tabled an estimate of expenses ... which showed that four 72-page issues a year at about $\$ 4000$ an issue, and with other expenses, could run to as much as $\$ 25000$ a year. All agreed that without a solid membership base a journal was out of the question, but Fischer did observe that a gradual movement towards such an objective, for instance by building on the newsletter and publishing biannually instead of quarterly, was possible. Emily Cain volunteered, should we have the necessary financial support, to look after typography. Mackenzie emphasised that we should be making a positive move towards a journal, and Fischer agreed, but thought such a move should begin with a membership drive and a newsletter. Moved by Fischer, seconded by Kert, to table the idea of a journal to be discussed next year.

These minutes appeared in the first newsletter of the society. This was published under the title The Canadian, with the subheading "WHAT TITLE DO YOU SUGGEST?". The next issue came out as Argonauta, a name suggested as the title

\footnotetext{
${ }^{11}$ LL.D (Honorary) University of Liverpool, MA, University of Toronto, MA, York University, Fellow of the Royal Historical Society and of the Society of Arts. His many contributions are described in David M. Williams and Lars U. Scholl, "Lewis R. Fischer and the Progress of Maritime Economic History" in G. Harlaftis and Tenold J. Valdaliso, eds., The World's Key Industry: History and Economics of International Shipping, (Springer, 2012).

${ }^{12}$ See Lewis R. Fischer, "Gerald E. Panting and the Development of Maritime History in Canada," The Northern Mariner, 3:3 (July 1993).

${ }^{13}$ BA, McMaster University, MA, PhD, Queen's University. Fellow of the Royal Historical Society. Member: International Maritime Economic History Association, Navy Records Society, Canadian Nautical Research Society, Newfoundland Historical Society, Society for Nautical Research. His area of research is the eighteenth century with an emphasis on Newfoundland and the North Atlantic.

${ }^{14}$ We had conducted several sessions during Canadian Historical Association conferences in previous years.
} 
of the journal rather than a newsletter, because we were assuming that the newsletter would turn into a journal rather than continuing as a separate publication. ${ }^{15}$

On 25 October, 1984, Letters Patent, issued by the Department of Consumer and Corporate Affairs, Canada, authorised incorporation of the Canadian Nautical Research Society. At the next annual meeting, 29 May 1985, having determined that American Neptune cost about \$10,000 an issue, Professor David McGinnis, of the University of Calgary, asked for sponsorship from the society to publish a feasibility report for a journal of maritime history, resulting in the motion: "The Canadian Nautical Research Society, in view of its stated intention of publishing a first class journal of nautical history, and its need to examine the feasibility of such a project, after careful review of the proposal for a feasibility study by Professor David McGinnis ...considers that this project merits endorsement by the society." By this time membership was up to 162, largely from Ontario, Quebec, Nova Scotia, British Columbia and Newfoundland, and the society had about $\$ 2300$ in the bank. Unfortunately, Professor McGinnis ${ }^{16}$ was not able at this time to follow through on the feasibility study he had proposed.

In June 1986 Ken Mackenzie, the editor of Argonauta, pointed out that the only person who had contacted him with constructive, optimistic comments about the society's journal was Skip Fischer, and he recommended a workshop on the theme "Towards the establishment of a Canadian Maritime History Journal." In his 1988 presidential address Professor Barry Gough ${ }^{17}$ spoke of a journal "of the highest quality, with excellent illustrations, design and layout." By this time our membership was over 200, and Argonauta was publishing extensive book reviews, edited by Skip Fischer and Olaf Janzen. Ken Mackenzie, who now found himself responsible for somewhat incompatible duties in the public service, found it necessary to step down as editor and Skip Fischer took over. The Maritime Studies Research Unit at Memorial University provided him with vital support, particularly with an editorial assistant, Margaret Gulliver, and in January 1989 he was "reasonably confident" that a journal, to be edited by Lewis Fischer, Olaf Janzen and Margaret Gulliver, would appear in $1990 .{ }^{18}$ Argonauta continued to appear as a newsletter, edited by Fischer, Panting and Janzen until 1997. Since then other

\footnotetext{
15 The entire run of Argonauta has been deposited in the Naval Marine Archive, Picton, Ontario. An incomplete set is to be found in the library of the Canadian War Museum, Ottawa.

16 A member of Calgary's Department of History, Professor McGinnis (1937-2004) had a wide range of interests. He eventually retired to turn his attention from economic history to fiction and poetry, but continued to review books for The Northern Mariner until 1993.

17 Professor Gough earned his doctorate from King's College, University of London, under the supervision of Gerald Graham, the Rhodes Professor of Imperial History. His thesis, The Royal Navy and the Northwest Coast of North America, 1810-1914: A Study of British Maritime Ascendancy, (1971) was the first book to be published by the University of British Columbia Press.

18 Margaret Gulliver, as assistant and finally managing editor, was vital to the creation of the journal. "We hired her in a full-time position for the International Journal of Maritime History," recalls Professor Fischer, "She remained, first as editorial assistant and later as managing editor, the entire time we edited The Mariner from Memorial."
} 
members of the society have taken over as editors of the newsletter, including the late William Schleihauf, Maurice Smith, Michael Hennessy, and Isabel Campbell. ${ }^{19}$

In January 1991 the first issue of The Northern Mariner/Le marin du nord (Barry Gough proposed the name) appeared with the editorial comment: "The Canadian Nautical Research Society has three primary goals: to stimulate nautical research in Canada; to enhance our understanding of Canada's maritime heritage; and to foster communications and co-operation among those interested in nautical affairs." Grant Macdonald's portrait of Harry DeWolf, Canada's most notable naval hero, ${ }^{20}$ graced the cover of volume, number one, in which the editors stated: "our principal goal is to publish essays on Canada, but given the international nature of maritime activities, it would be foolish to preclude contributions which either seek to place the experience into an international perspective or to present new evidence on a non-Canadian topic."

The contents that issue were somewhat prophetic. David Beatty writing on the Monroe Doctrine and the Ogdensburg agreement of 1947, and John Stanton on the 1945 Green Hill Park disaster in Vancouver, touched on sensitive issues in Canadian-American relations, and the impact of war on Canadian shipping that recalled the terrible Halifax disaster of $1917 . .^{21}$ The second volume contained a remarkably wide range of articles on the Canadian merchant marine, the law of the sea and shipbuilding, including the first French language article by Nicolas Landry: "Les Pêches canadiennes au XIXe siècle." The April issue of volume two, as suggested by the cover illustration of Captain Tom Pullen, RCN (Ret), contained Captain Pullen's reminiscence of Convoy ON 127 when he survived the sinking of HMCS Ottawa in 1942, an article by Graham Rowley on Tom Pullen's contributions to polar navigation, and a bibliography of Captain Pullen's arctic writings.

\footnotetext{
${ }^{19}$ Since the winter issue of 2013 the newsletter has been produced electronically rather than in print. As noted in the website for the society, "Besides serving as the CNRS newsletter, it also provides a place for articles less formal than those which would appear in The Northern Mariner. It is also the best place for queries and small research notes."

${ }^{20}$ From the collection at the Marine Museum of the Great Lakes, Kingston, this portrait by Grant Macdonald was painted in 1942 when DeWolf was director of plans at Naval Headquarters, Ottawa, two years before he won special distinction while in command of HMCS Haida in the English Channel. The artist, as a lieutenant (special branch) in the Royal Canadian Naval Volunteer Reserve, created hundreds of portraits of ordinary sailors performing their regular duties. According to Vice Admiral G.C. Jones, the chief of naval staff, "All received his attention in a manner that has made it possible to show with admirable insights the hearts and souls of the men who so valiantly helped fight and win the Battle of the Atlantic." He died in 1987. His work is represented in collections the Marine Museum of the Great Lakes, and the Agnes Etherington Art Centre at Queens University, as well as private collections.

${ }^{21}$ Hugh MacLennan, Barometer Rising (Toronto: Collins, 1941) and John Armstrong The Halifax Explosion and the Royal Canadian Navy (Vancouver: UBC Press, 2002) are among the major references for this topic, which was also discussed in later issues of The Northern Mariner.
} 
One of the original members of the society, Fraser McKee, ${ }^{22}$ who in 2012 was awarded the Admirals' Medal for his contributions to Canadian naval history ${ }^{23}$ contributed two articles in 1993 about U-boat kills and the disposal of depth charges, reflecting his own experience in the RCNVR from 1943-1945. He has been one of the most consistent and prolific book reviewers for the journal, with fiftynine reviews over the past twenty-five years. His many contributions to Argonauta include "Captured Italian Submarines: (the ones we never hear about);" "The Auxiliary Carriers" (a detailed listing and explanation of FCS, CAM and MAC ships); "U-boat C/O's lost 'due to other means;" "What does 'ASDIC' mean," and "Where did the Fairmiles go?".

In 1994 several groundbreaking articles appeared. Richard Gimblett, ${ }^{24}$ then a member of the Directorate of History at Canadian Forces Headquarters, published his reassessment of the Dreadnought Crisis and the origins of the RCN, based on his master's thesis at Trent University, in Peterborough, Ontario. David Syrett, Distinguished Professor of History at Queens College, City University of New York, was the first contributor from the United States, with his analysis of the Murmansk Convoys, anticipating his 1998 volume on signals intelligence for the Navy Records Society. ${ }^{25}$ The first book review by Louis Audette, an RCNVR officer who had commanded escort vessels during the Second World War, and was one of the commissioners for the so-called Mainguy Commission, was also noteworthy, and appeared in this volume. His discussion of Invergordon Scapegoat: the betrayal of Admiral Tompkinson, by Alan Coles, reflected his own experience. "I have no special knowledge of Invergordon," wrote Audette, "but I say unhesitatingly the

\footnotetext{
${ }^{22}$ Fraser McKee, who has deposited his papers in the Directorate of History, National Defence Headquarters, served in the RCNVR, 1943-1945, served in armed yachts, and the convoy escorts Wallaceburg and Royalmount. After the Second World War, he attended the University of Toronto where he obtained a degree in forestry, and was employed with a directory publishing company as a finance manager. He remained in the naval reserves, specializing in anti-submarine warfare. His books include The Armed Yachts of Canada, (1983), HMCS Swansea,(1994), The Canadian Naval Chronicle, (1995), Sink all the Shipping There, (2003), Three Princes Armed: Luxury Liners to Warships,(2008) and the novel Ellesmere Pickup.(2013), all published by Vanwell, St Catherines, Ontario.

${ }^{23}$ The Admirals' Medal, an award founded by three retired Canadian vice admirals, Robert Stephens. Nigel Brodeur, and the late Daniel Mainguy, the only three in the RCN whose fathers were admirals in the RCN before them, has been awarded annually since 1985 , (the $75^{\text {th }}$ anniversary of the Royal Canadian Navy), to recognize special contributions to Canadian maritime endeavour. Other recipients include several present and past members of the CNRS.

${ }^{24}$ Richard Gimblett was appointed to the Directorate of History in 1992 to prepare a history of Canadian naval operations in the Persian Gulf in 1990-91. He had served as the combat officer of HMCS Protecteur, a previously unarmed supply ship. Lieutenant Commander Gimblett and Major Jean Morin, of the Directorate of History, who had served as field historian on the staff of Commodore Ken Summers (commander Naval Forces Middle East), subsequently co-wrote Operation Friction: The Canadian Forces in the Persian Gulf, (Toronto: Dundurn Press, 1997). Richard Gimblett later published Operation Apollo: The Golden Age of the Canadian Navy in the War against Terrorism (Ottawa: Magic Light Publishing, 2004). He was deeply involved with the production of Leadmark: The Navy's Strategy for 2020 (Ottawa: Department of National Defence, 2001), and now is the official historian for Maritime Command,

${ }^{25}$ David Syrett (1939 - 2004), The Battle of the Atlantic and Signals Intelligence U-Boat situations and trends, 1941-1945, (Navy Record Society, Vol.139, London: Ashgate, 1998).
} 
British were fools not to do the same [as the Mainguy Commission]. Had they done so there would not have been the tergiversations lasting to this day and showing the Sea Lords not only to be a pack of fools but pack of mean-spirited fools." ${ }^{26}$

In the first issue of 1996 Roger Sarty, ${ }^{27}$ in a review of Joseph Prim and Mike McCarthy Those in Peril The U-boat Menace to Allied shipping in Newfoundland and Labrador waters World War I and World War II, drew attention to the remarkable statement by John Collins ${ }^{28}$ in the book's introduction: "So little regard for those who initiate wars are the crushing anxieties suffered by parents of sons and daughters serving in overseas and near-shore war zones. At the time of my brother's death, when I myself was at sea, my mother became aware of the local priest sorrowfully approaching our home on Patrick Street in St John's. On opening the front door to him, her first words were, 'which one, Father?' No mother should ever have to ask such a question."

Although early editions of the journal reflected its Canadian origins, the editors had already cultivated a stable of reviewers and contributors from Europe and the United States. Memorial University had for some time been publishing The International Journal of Maritime History. However, by 2001, after the death of Gerald Panting in 1998, and Skip Fischer's subsequent serious illness, publication of the two journals was becoming increasingly difficult. Consequently CNRS undertook full responsibility for editing and publishing The Northern Mariner. Skip Fischer and Olaf Janzen of Memorial turned over editing responsibilities to William Glover of Kingston, Ontario, and Gregory Kennedy of King's College, London became book review editor until a replacement could be found in Canada. ${ }^{29}$ In 2002

\footnotetext{
26 "A capable and well-liked officer, ... [Admiral Edmund Rollo Mainguy] chaired a commission in 1949 investigating several mutinies in the fleet. The resulting "Mainguy Report" recommended improvements in the handling of lower-deck grievances," ("Mainguy, Edmund Rollo," The Canadian Encyclopedia). The two other commissioners were Louis Audette (1907 - 1995), (see Louis de la Chesnaye Audette fonds National Defence Headquarters Directorate of History and Heritage), and Leonard Brockington (1888 - 1966), the first head of the Canadian Broadcasting Corporation, and a long serving Rector of Queen's University, Kingston. Louis Audette was the second recipient of the Admirals' Medal, in 1986.

${ }^{27}$ Roger Sarty, a Nova Scotian by birth and temperament, began his academic career in 1981 as a researcher in the Directorate of History at National Defence Headquarters. Already immensely knowledgeable about coastal artillery, he soon became an authority on the history of naval operations, and was one of the authors of note for the official history of the Royal Canadian Navy. In 1998 he went to the Canadian War Museum to assist Professor Jack Granatstein strengthen the museum's historical research program. With the government's approval of a new museum building in 2000, Sarty became deputy director with responsibility for all exhibition development. In 2004 he became a professor of naval, military and Canadian history at Wilfrid Laurier University.

${ }^{28}$ John Collins (1922 - 2016) was a distinguished physician and Newfoundland provincial cabinet minister. During the Second World War he was a radio operator in merchant ships. His service included convoys to Murmansk.

${ }^{29}$ William Glover, BA (Queens University), MA and PhD (University of London), formerly attached to the Directorate of History at National Defence Headquarters, had taken an early retirement from the navy in 2000 to pursue his own academic interests. Gregory Kennedy, BA (Saskatchewan), MA (Royal Military College), $\mathrm{PhD}$ (University of Alberta) had recently moved to King's College, London. He continued as book reviews editor until 2002, when David Zimmerman of the University of British Columbia took over the task, pro tem, until Faye Kert was able to relieve him in 2003.
} 
David Zimmerman of the University of British Columbia took over as book review editor, and in 2003 Faye Kert relieved him. She has continued ever since as an indefatigable editor with excellent international connections.

Over the next five years the journal contained an interesting variety of content, including for the first time French language summaries of articles. There were also welcome contributions from an increasingly diverse range of historians. In the second issue of 2002, for example, Lewis Johnman (University of Westminster) and Hugh Murphy, (a research associate at the University of Glasgow), noted, with regard to the British merchant shipping mission in the United States, and British merchant shipbuilding in the Second World War that "British shipbuilders failed to make the changes so clearly enshrined in US production methods in the Second World War and established the parameters for the decline in British shipbuilding in the post 1945 period." George Bolotenko, of the National Archives of Canada, contributed a valuable article on the icebreaker Mikula Selianinovitch, 1916-1937, and David Syrrett continued his analysis of wartime convoys with HX 133. Among the interesting contributions in 2003 was Ken Hansen's criticism of the Canadian naval establishment for selecting inappropriate ship types for the RCN between the wars. Admiral Kingsmill, he argued, had the much better realisation that cruisers and sloops would have been the best mix for the interwar RCN, an argument that could, and probably should, have led to a vigorous discussion of Canadian shipbuilding decisions, but it was another ten years before Canadian official historians were able to turn their attention to Canadian naval policy before the Second World War. O.M Meehan's history of the Canadian Hydrographic Service from 1833-1945, edited by Bill Glover in 2004, and a full index of that work which appeared in 2005 , also deserve special notice.

The 2005 issues merit special attention. In the first issue there is an article on the cancellation of Operation Chopper during the invasion of Sicily, based on the Ramsay papers in Churchill College, Cambridge, contributed by the former editor of the Mariner's Mirror, Richard Harding; a fascinating research note by James M Whalen of Fredericton, New Brunswick summarising the log of Lieutenant Charles Cockayne Austen, the brother of the English novelist Jane Austen, who served in HMS Crocodile on the North American and West Indies station in the critical years of 1838 and 1839; and an account by David Gray, late of the Canadian Hydrographic Service, ${ }^{30}$ about Sir Wilfred Grenfell, who "although often remembered for his medical mission along the Labrador coast, should be remembered, particularly by the nautical historians, for his hydrographic work of sketch surveys, sailing directions and panoramic views that were necessary as an adjunct to his medical work and a benefit to all navigators of that coast for the one hundred and thirteen years since he first arrived in Labrador." A recollection by

\footnotetext{
${ }^{30}$ David Gray "started consulting work in 2005 after leaving the Canadian Hydrographic Service after thirty-four years of providing ... advice to Canadian government officials in several different departments. With his Danish counterpart, he recomputed 1,500 km. of the Canada-Greenland boundary after adjusting the geodetic coordinates along both coasts to the same geodetic datum. He was technical expert to the Nova Scotia-Newfoundland \& Labrador offshore resource boundary tribunal." See https://www.acls-aatc.ca/files/abstract/Bio\%20Gray.pdf
} 
Thomas Hampson, “Challenger's wintering party 1932-3: a Labrador journal," edited by William Glover, is "important for two reasons. First, it offers an observer's account of the wintering party, left by HMS Challenger, to complete coast line information for the survey of the Labrador coast. Second, and perhaps more important, it was written by a member of the lower deck. Such accounts are rare, most journals or diaries having been kept by officers."

The second issue of 2005 contained the first of several articles by Carmen Depasquale of the University of Malta, and the third issue was dedicated to Skip Fischer. The editor's comments in this issue are noteworthy. Clearly, as Bill Glover acknowledged, the society owes an enormous debt to him. Roger Sarty, who was then chair of the editorial board, observed: "Skip is one of those rare people (and perhaps even rarer scholars!) who combines imagination and breadth with the ability to make things happen, most notably in mastering the myriad details of such an ambitious enterprise as making a scholarly journal. As founding editor he nurtured the journal for its critical first decade, not least by personally applying his superb blue pencil to much of the content. He is quite simply one of the best editors of the English language in the business. At the same time he encourages authors with remarkable generosity and an immense understanding of the furthest reaches of the maritime history field."

In 2004 Paul Adamthwaite, chair of the Archives and Collections Society (Naval Marine Archive since 2012) of Picton, Ontario, was invited to join council. He served as executive editor from 2006 -15, was vice president under Richard Gimblett in 2006-7, and from 2008-9 under Maurice Smith, the former director of the Marine Museum in Kingston, Ontario. ${ }^{31}$ From 2009 to 2011 Paul Adamthwaite was president of CNRS. ${ }^{32}$

Meanwhile, in August 2006, The Northern Mariner had become the journal for $\mathrm{NASOH}$ as well as CNRS. This was a much anticipated and welcome development, and it coincided with a change of editors, resulting from the election of Bill Glover to city council in Kingston, Ontario. Roger Sarty would later comment, in the final issue of 2007, that "CNRS, like NASOH, was founded in the hopes of encouraging transoceanic communication and combined enterprises, not unlike the sea itself." Among notable book reviews in that edition was James Pritchard ${ }^{33}$ on Alex Roland,

\footnotetext{
${ }^{31}$ Maurice Smith, a former merchant mariner, has been one of the most active members of the society from its beginnings, maintaining important connections with shipping industries and historians in Britain and Canada. As noted above he has also served as one of the editors of Argonauta.

${ }^{32}$ Paul Adamthwaite is one of those rare people bred to the sea. Born in the UK within a mile of the sea, he began sailing as soon as he could walk and owned his first very old vessel at the age of ten. While serving in the Royal Navy he specialized in mathematics, and earned a $\mathrm{PhD}$ at the University of Clermont-Ferrand, now known as Université Blaise Pascal, in the Auvergne region of France. After leaving the navy he sailed alone around the world in a small boat before trading up to a 54-foot yawl Stormy Weather in the West Indies, and commuted yearly between the West Indies and Europe. While in the West Indies some years later he met his future wife, Betty Ann Anderson of Picton, where they have now both settled.

${ }^{33}$ James Pritchard (1939 - 2015), president of the CNRS in 2004-6, well known for his superb studies of the French navy in the seventeenth century such as In Search of Empire, The French in the Americas, 1670-1730, (Cambridge University Press, 2004), was at this time turning his
} 
W. Jeffrey Bolster and Alexander Keyssar The Way of the Ship: America's Maritime History Reenvisioned 1600-2000. ${ }^{34}$ In 2007 Peter Haydon, who had been serving in $\mathrm{RN}$ submarines on loan to the RCN during the Cuban Crisis of 1962, commented on the most recent developments in analysis of that event. "Modern navies," he observed," are superbly versatile political instruments always ready to do the bidding of their political masters in any corner of the world at short notice. Armies and Air Forces cannot make that claim; navies are unique in this respect."

With the enthusiastic assistance of Paul Adamthwaite, Roger continued as editor until 2015. His variety of responsibilities, as head of the Centre for Military, Strategic and Disarmament Studies at Wilfrid Laurier University, and editor of Canadian Military History, despite his enormous capacity for work, persuaded him to relinquish his editorship of Northern Mariner. Bill Glover, whose activities in municipal politics had come to an end, has now resumed the task.

In 2008 a double issue, numbers three and four, was devoted to NASOH papers which had been awaiting publication since 2005. William Dudley, the former director of the Naval Historical Center in Washington, DC, introduced this collection with an essay entitled "Troubled Waters: New Aspects of Maritime and Naval History". As Roger Sarty explained "When ... the CNRS executive learned that our colleagues were searching for a publisher for the outstanding papers presented at NASOH conferences in 1990-2005, it seemed natural that the journal should be the venue, There was a minimum of discussion and a good deal of action. Bill Dudley, editor of the NASOH collection, effectively joined the journal editorial team, and we have worked together to edit the papers he assembled. The team included a new member, Dr. Robert L. Davison, ${ }^{35}$ who teaches history at Wilfrid Laurier University and he did the first style revisions of many of the papers in the collection." A wonderful overview of scholarship in United States maritime history, this issue added significantly to the international scope of the The Northern Mariner/Le marin du nord.

In 2009 Jonathan Dull's brilliant article "The Myth of French Abandonment" (which observed that "Louis XV lost Canada but he saved the French Navy and became posthumously a major architect of American independence"), in the opinion of the awards committee of the CNRS, "gives a new interpretive insight on a big issue: the relationship between European and North American operations in the Seven Years War from the French perspective." It earned the Keith Matthews award for the best article for 2009. There were three other articles of unusual significance in that issue: Peter Macleod on Admiral Phillip Durell, whose crucial contribution to the 1759 campaign in Quebec has so often been ignored; Donald Schurman on

attention to Second World War naval construction in Canada, and in 2011 would publish A Bridge of Ships; Canadian Shipbuilding during the Second World War, (McGill-Queen's University Press, 2011) after retiring from Queens University. His sudden and premature death in April 2015 was recognized with the obituary published in, Northern Mariner, 25:1 (January 2015).

${ }^{34}$ John Wiley \& Sons, 2008

${ }^{35}$ Robert Davison, who served as secretary of CNRS until 2012, published The Challenges of Command: The Royal Navy`s Executive Branch Officers 1880-1919 (Burlington VT: Ashgate, 2011). He may well have a unique CNRS connection in that he did his MA under Barry Gough at Wilfrid Laurier and his PhD under Skip Fischer at Memorial. 
Sir Julian Corbett at the Quebec Centenary in 1907, (a chapter from his biography of Corbett that Roger Sarty had persuaded him to publish in the journal); and Robert Davison on the 1907 court martial, of Captain William Kingsmill, who in 1909 would become the Chief of Naval Staff for the RCN, for putting his ship aground in New Brunswick.

In 2012 Chris Madsen, professor of naval history and military law at the Canadian Forces College in Toronto, followed Paul Adamthwaite as president of the society. At the time of writing Chris, who is on sabbatical leave, is visiting scholar at the Urban Studies Program of Simon Fraser University, Vancouver. ${ }^{36}$ It is of interest that the present secretary of the society, Michael Moir, university archivist and head of the Clara Thomas Archives and Special Collections at York University in Toronto, is also engaged in the history of Canadian shipbuilding. ${ }^{37}$

As Bill Glover resumes his labour as editor, readers must acknowledge the extraordinary contribution of Roger Sarty, who in ten years has persuaded so many and such admirable scholars to publish in this journal. The ten volumes which have appeared under his editorship, as Paul Adamthwaite has pointed out, "account for just over half the 'word count' of all Northern Mariners." Indeed, the various editors of this journal, celebrating the conclusion of its $25^{\text {th }}$ year, deserve our admiration and our gratitude. We wish them continuing success in the years to come.

\section{Presidents of the Canadian Nautical Research Society}

1982 - 1984 Professor Keith Matthews, Memorial University of Newfoundland 1984 - 1987 Professor Gerald Panting, Memorial University of Newfoundland 1987 - 1990 Professor Barry Gough, Wilfrid Laurier University

1990 - 1993 Dr W.A.B. Douglas, Directorate of History, Department of National Defence

1993 - 1996 Dr Faye Kert, Department of Health and Welfare

1996 - 1999 Mr G. Edward Reed ${ }^{38}$, Bank of Canada

1999 - 2002 Dr William Glover, Kingston, Ontario

2002 - 2005 Professor James Pritchard, Professor Emeritus, Queen's University

2005 - 2008 Dr Richard Gimblett, Maritime Command official historian, Ottawa, Ontario

2008 - 2011 Dr Paul Adamthwaite, Picton, Ontario

2011 - 2014 Mr Maurice D. Smith, Kingston, Ontario

2015 - $\quad$ Dr Christopher Madsen, North Vancouver, B.C.

\footnotetext{
${ }^{36}$ Chris Madsen has in the past seven years made significant contributions to our knowledge of shipbuilding in Canada, particularly in the Second World War.

${ }^{37}$ Just before he died, the late Jim Pritchard passed his research notes on Canadian shipbuilding to Michael, who, I am sure, will add to the work that has been done by Pritchard and Madsen.

${ }^{38}$ The late Ed Reed was a remarkable member of the society. He had first offered his services as treasurer in 1990, an offer from someone so familiar with double entry bookkeeping that could not be refused! His interest in maritime history was such that he won friends and influenced them to the extent that he became a logical choice to replace Dr Kert as president in 1996)
} 